\title{
АНАЛІЗ ПОЛОЖЕНЬ ІНСТРУКЦІї З ОРГАНІЗАЦІї ДІЯЛЬНОСТІ ДІЛЬНИЧНИХ ОФІЦЕРІВ ПОЛІЦІї
}

Медведенко С. В.

у статmі проаналізовано один із нормативно-правових актів, який детально регламентує діяльність дільничних офіцерів поліції. Положення Інструкції з організації діяльності дільничних офіцерів поліціі складається з семи розділів, які логічно розкривають від загального до конкретного зміст діяльності, поняття та загальні характеристики служби дільничних офіцерів поліції.

В сучасних умовах правоохоронні органи, зокрема Національна поліція України, потребують підтримки та допомоги від громадськості. Громадські помічники співпрацюватимуть із поліцейськими на постійній основі, що відрізняє їх діяльність від допомоги волонтерів, чия діяльність як правило $\epsilon$ періодичною, короткостроковою або разовою. Громадські помічники (позаштатні працівники), закріплені за підрозділом чи конкретним працівником поліції, зможуть надавати більш вагому допомогу саме завдяки регулярній співпраці, накопиченню інформації, отриманих знань, досвіду. Запропоновано пропозиції та рекомендації до Інструкції з організації діяльності дільничних офіцерів поліції.

Ключові слова: інструкція, реформа поліції, діяльність, національна поліція, дільничний офіцер поліції.

В статье осуществлен анализ нормативно-правового акта, которым детально определяется деятельность участковых офицеров полиции. Инструкция организации деятельности участковых офицеров полиции состоит из семи разделов, логично раскрывающих от общего к частному содержание деятельности, понятие и общие характеристики службы участковых офичеров полиции.

Для эффективного выполнения задач и функций правоохранительным органам, в частности Национальной полиции Украины, необходима поддержка со стороны общественности и населения. Помощники полиции, в отличие от волонтеров, чья деятельность обычно является периодической, краткосрочной или разовой, сотрудничают с полицейскими постоянно. Общественные помощники (внештатные сотрудники), закрепленные за подразделением или конкретным полицейским, смогут оказывать более весомую помощь именно благодаря регулярному сотрудничеству, накоплению информации, полученных знаний, опыта. Внесены конкретные предложения и рекомендации к Инструкции организации деятельности участковых офицеров полиции.

Ключевые слова: инструкция, реформа полиции, деятельность, национальная полиция, участковый офицер полиции.

The article analyzes the regulatory act, which regulates in detail the activities of district police officers. The instruction on the organization of activities of local police officers consists of seven sections, which logically disclose, from general to particular, the content of the activity, the concept and general characteristics of the service of local police officers. Becoming Ukraine, as a democratic state, is connected with multifaceted processes in the spheres of socio-economic and political life of the society. In the conditions of radical reforming, the usual stereotypes, views on understanding different problems of social life are broken.
For the effective implementation of tasks and functions, law enforcement agencies, in particular the National police of Ukraine, need support from the public and the public. Police assistants, unlike volunteers, whose activities are usually periodic, short-term, or one-time, work with the police constantly. Huge amount of servants, who are locked behind a specific police officer, can press a little more to help you myself, $i$ can help you regularly, i'm more knowledgeable. Police officers within the police station carry out public awareness work for the formation of a legal culture, negative attitudes towards socially dangerous phenomena in order to raise the image of the police, and ways to protect and defend themselves against criminal offenses.

Until 2017, the police (militia) of Ukraine had experience of working with citizens as freelance workers, who were selected from the number of citizens who positively proved themselves in education, work and at the place of residence, as well as from the number of pensioners - former law enforcement officers, later with the number of members of public order formations who had the specified features. A sociological survey conducted by police officers confirms the following situation: $72 \%$ of the police polled agree with the need to involve public assistants (freelance workers).

Public-service freelance staff assisted and assisted police (militia) staff in undertaking law enforcement, crime-fighting, crime-prevention, including internal affairs agencies, and other tasks. No regulatory document is perfect and needs to be amended. Definition proposed: police officer is a police officer who serves the community by ensuring the protection of human rights and freedoms, combating crime, maintaining public safety and order, empowered with the right to apply preventive and coercive measures of influence provided by the legislation of Ukraine and operating within a fixed police station.

It is proved that the assistant police officer of the police is a police officer who serves the society by ensuring the protection of human rights and freedoms, combating crime, maintaining public safety and order, whose activities are based on the principle of partnership with the public and operate within the bounded police station under control of a police officer. Attention is drawn to the fact that a separate section provides the following section in the Instruction: "Public (Freelance) police officer". Having defined the concept and legal status of a freelance police officer. Other suggestions and recommendations have been provided to the Instruction on organizing the activities of police officers.

Key words: instruction, public, police reform, activity, national police, a police station officer.

Постановка проблеми та її актуальність. Становлення України як демократичної держави, пов'язано з багатогранними процесами у сферах соціально-економічної та політичної життєдіяльності соціуму. В умовах радикального реформування здійснюється переосмислення звичних стереотипів, поглядів на розуміння різних проблем суспільного життя. 
Сучасний стан правоохоронної діяльності в Україні знаходиться на стадії реформування, особливо гостро постають питання, які стосуються забезпечення публічного порядку та безпеки. Найширший спектр завдань у силу функціональних обов'язків покладаються саме на Національну поліцію України [1, с. 19]. При цьому актуальності набувають питання ефективного врегулювання діяльності служб і підрозділів Національної поліції України. Якісне виконання поліцейської діяльності не можливе без належного нормативно-правового забезпечення.

Мета статті - здійснити аналіз положень Інструкції з організації діяльності дільничних офіцерів поліції, надати пропозиції та рекомендації щодо вдосконалення цього підзаконного нормативно-правового акту.

Виклад основного матеріалу. 3 початку реформи правоохоронної діяльності було прийнято низку нормативно-правових актів, які регламентують діяльність підрозділів Національної поліції України: Закон України «Про Національну поліцію», наказ МВС України № 650 [2] та інші нормативні акти.

Враховуючи напрям цього дослідження, автор провів аналіз Наказу МВС України № 650 «Про затвердження Інструкції з організації діяльності дільничних офіцерів поліції» [2]. Документ складається з семи розділів, які логічно розкривають його зміст від «Загальних положень» до «Матеріально-технічного забезпечення дільничних офіцерів поліції».

В інструкції закріплено такі терміни: «звіт дільничного офіцера поліції», «поліцейська дільниця», «поліцейська станція», «превентивна (профілактична) робота дільничного офіцера поліції», «превентивний облік» (розділ І, пункт 4) [2], які розкривають особливості діяльності дільничного офіцера поліції (далі дОП). На думку автора, у цьому пункті необхідно було $б$ надати визначення «дільничний офіцер поліції».

Визначено й основні напрями діяльності ДОП:

1) здійснення профілактичної роботи, спрямованої на запобігання вчиненню кримінальних та інших правопорушень;

2) виявлення причин та умов, які призводять до вчинення кримінальних та адміністративних правопорушень, вжиття у межах компетенції заходів для їх усунення;

3) вжиття заходів, спрямованих на усунення загроз життю та здоров'ю фізичних осіб і публічній безпеці, що виникли внаслідок вчинення кримінального, адміністративного правопорушення;

4) здійснення своєчасного реагування на заяви та повідомлення про кримінальні, адміністративні правопорушення або події;

5) у випадках, визначених законом, здійснення провадження у справах про адміністративні правопорушення, прийняття рішення про застосування адміністративних стягнень і забезпечення їх виконання;

6) доставляння у випадках і порядку, визначених законом, затриманих осіб, підозрюваних у вчиненні кримінального правопорушення, та осіб, які вчинили адміністративне правопорушення [2].

Розділом III регламентуються питання взаємодії дОП із населенням. ДОП із метою впровадження принципу взаємодії з населенням на засадах партнерства організовує роботу за такими напрямами:

1) протидія злочинності, профілактика правопорушень та охорона публічного порядку за участю населення;
2) співпраця з органами місцевого самоврядування, представниками територіальних громад, населенням, керівниками підприємств, соціальних, навчальних і культурних закладів, закладів захисту дітей з метою реалізації принципу взаємодії з населенням на засадах партнерства, обмін інформацією для подальшого їі використання під час виконання службових обов'язків;

3) визначення спільних пріоритетних напрямів роботи та її оцінювання з урахуванням думки і потреб громадськості.

ДОП проводить відкриті зустрічі з представниками органів місцевого самоврядування областей, районів, міст і сіл з метою налагодження ефективної співпраці між поліцією та органами місцевого самоврядування і населенням. Інформує про стан законності, боротьби зі злочинністю, охорони громадського порядку та результати діяльності на відповідній території. ДОП у межах поліцейської дільниці проводить серед населення роз'яснювальну роботу для формування в нього правової культури, негативного ставлення до суспільно-небезпечних явищ з метою підняття іміджу поліції, повідомляє про способи захисту і самооборони від злочинних посягань.

ДОП у взаємодії з органами соціального захисту населення, місцевих органів виконавчої влади, органів місцевого самоврядування, службами у справах дітей, благодійними, громадськими організаціями, представниками територіальних громад, спеціалізованими установами для осіб, які відбули покарання, здійснює роботу із запобігання вчиненню правопорушень, у тому числі стосовно осіб, які перебувають у складних життєвих обставинах [2]. ДОП формує пропозиції щодо:

1) усунення причин та умов, які призводять до вчинення правопорушень;

2) вжиття заходів з метою запобігання вчиненню насильства в сім'ї, надання соціальних послуг особам / сім'ям, які перебувають у складних життєвих обставинах;

3) створення громадських формувань з охорони громадського порядку та державного кордону та/або призупинення (припинення) діяльності таких формувань, які неналежним чином виконують свої обов' язки, визначені нормами Закону України «Про участь громадян в охороні громадського порядку і державного кордону»;

4) покращення матеріально-технічного забезпечення поліцейської станції та умов роботи;

5) надання необхідної допомоги особі, яка постраждала від торгівлі людьми.

ДОП здійснює прийом населення у приміщенні поліцейської станції або іншому місці. При виявленні на території поліцейської дільниці інших порушень, реагування на які не належить до повноважень поліції, ДОП інформує про це відповідні уповноважені органи.

У розділі IV інструкції «Особливості організації роботи дільничного офіцера поліції на поліцейській дільниці» зустрічається словосполучення «помічник дільничного офіцера поліції», хоча не надається визначення цього терміну, не визначається правовий статус помічника дільничного офіцера поліції. У пункті «8» цього підрозділу вказано: «На період тривалої відсутності дОП (відпустка, навчання, хвороба, відрядження) його обов'язки покладаються на іншого ДОП або помічника ДОП з обов'язковим інформуванням відповідних виконавчих органів місцевого самоврядування», щоб було можливо встановити, що помічник ДОПє поліцейським». 


\section{Правове забезпечення адміністративної реформи}

Необхідно звернути увагу на те, що поліція (міліція) України до 2017 року мала досвід співпраці з громадянами в якості позаштатних працівників (позаштатних дільничних інспекторів поліції, позаштатних працівників ДАІ, позаштатних працівників органів дізнання, чергових частин, довірених осіб та громадських помічників дільничних інспекторів міліції), які спочатку підбиралися з числа громадян, які позитивно зарекомендували себе в навчанні, роботі та за місцем проживання, а також із числа пенсіонерів - колишніх працівників правоохоронних органів, пізніше з числа членів громадських формувань з охорони громадського порядку, які мали вказані особливості. Позаштатні працівники на громадських засадах надавали допомогу і сприяли діяльності працівників поліції (міліції) у здійсненні заходів щодо охорони правопорядку, боротьби зі злочинністю, профілактики правопорушень, у тому числі особами, які перебувають на обліку органів внутрішніх справ, вирішували інші завдання.

У Наказі МВС України № 550 від 11 листопада 2010 року «Про затвердження Положення про службу дільничних інспекторів міліції в системі Міністерства внутрішніх справ України» було надано надано роз'яснення поняття дільничного (старшого) інспектора міліції як «посадової особи органу внутрішніх справ, на яку покладено виконання завдань служби дільничних інспекторів міліції та яку наділено повноваженнями відповідно до законодавства».

Під час змін нормативно-правової бази, яка супроводжувала реформування правоохоронних органів, були втрачені положення, що регламентували наявність і діяльність позаштатних працівників. У сучасних умовах правоохоронні органи, зокрема Національна поліція України, потребують підтримки та допомоги громадськості. Громадські помічники (позаштатні працівники) мають співпрацювати із поліцейськими на постійній основі, що відрізняє їх діяльність від допомоги волонтерів, чия діяльність як правило є періодичною, короткостроковою чи разовою.

Громадські помічники (позаштатні працівники), закріплені за підрозділом чи конкретним працівником поліції, зможуть надавати більш вагому допомогу саме завдяки регулярній співпраці, накопиченню інформації, отриманих знань, досвіду. Враховуючи, що в якості позаштатних працівників обов'язково рекомендується залучати колишніх працівників правоохоронних органів, то вони не лише матимуть необхідний досвід, а й зможуть поділитися ним із молодими працівниками Національної поліції України. Допомога таких помічників особливо важлива в сільській місцевості, де територія обслуговування географічно значно більша і для ДОП громадські помічники також стануть «очима та вухами».

Проведене анкетування серед працівників поліцейських підрозділів підтверджує зазначену інформацію: 72\% опитаних поліцейських погоджуються 3 думкою про необхідність залучення громадських помічників (позаштатних працівників). Так у 2016 році в селі Стара Збур'ївка Херсонської області понад два роки працювали два місцеві громадські помічники дільничних. Місцеві жителі звикли, що $є$ «шерифи», які профілактують і викривають злочини. Результат не забарився: кількість правопорушень у цьому населеному пункті в 8 разів менша, ніж у сусідніх, де немає помічників дільничних. Про громадських правоохоронців зі Старої Збур'ївки навіть було знято документальний фільм «Українські шерифи» (режисер Роман Бондарчук), який висувався від України для номінації на «Оскар» у 2016 році [3].

Громадськість потребує та вимагає повернути можливість співпраці в якості постійних помічників чи працівників на громадських засадах. Так, це питання підіймалося правозахисниками під час виїзного засідання Громадської ради при МВС, яке відбулося 19 червня 2018 року в Маріуполі Донецької області [3]. Також було направлено звернення до Міністра внутрішніх справ і голови Національної поліції щодо необхідності нормативно-правової регламентації діяльності громадських (добровільних) помічників дільничних офіцерів поліції, на яке, на жаль, була надана формальна, загальна, неконкретна відповідь.

У розділі V. «Організація роботи дОП з особами, які перебувають на превентивному обліку», приділена увага превентивним заходам, до яких $є$ можливість залучення представників громадськості: «ДОП здійснює превентивні заходи щодо осіб, схильних до вчинення правопорушень, та осіб, які перебувають на обліку в органах поліції, для попередження вчинення ними правопорушень із залученням до цієї роботи громадськості».

Висновки. Підбиваючи підсумки змісту Інструкції з організації діяльності дільничних офіцерів поліції», автор пропонує такі зміни та доповнення:

1 пункт 4 Розділу I «Загальні положення» доповнити такими визначеннями:

«Дільничний офіцер поліції - це поліцейський, який служить суспільству шляхом забезпечення охорони прав і свобод людини, протидії злочинності, підтримання публічної безпеки і порядку, наділений правом застосування профілактичних і примусових заходів впливу, передбачених законодавством України, та діє у межах закріпленої поліцейської дільниці»;

«Помічник дільничного офіцера поліції - це поліцейський, який служить суспільству шляхом забезпечення охорони прав і свобод людини, протидії злочинності, підтримання публічної безпеки і порядку, діяльність якого ґрунтується на принципі взаємодії з населенням на засадах партнерства та діє у межах закріпленої поліцейської дільниці під контролем дільничного офіцера поліції»;

підпункт 1) пункту 1 «Завданнями ДоП $є: »$ розділу II «Завдання, основні напрями діяльності та повноваження ДОП» після словосполучення «... співпрацю з громадянами...» доповнити такими словами: «іноземцями, біженцями та особами без громадянства»;

підпункт 2) пункту 1 «Завданнями дОП є:» розділу II «Завдання, основні напрями діяльності та повноваження ДОП» словосполучення «громадськими формуваннями з охорони громадського порядку» замінити словами «громадськими об'єднаннями» (громадське об'єднання - це добровільне об'єднання фізичних осіб та/або юридичних осіб приватного права для здійснення та захисту прав і свобод, задоволення суспільних, зокрема економічних, соціальних, культурних, екологічних та інших інтересів [4]);

пункт 2 «Основні напрями діяльності ДОП» розділу II. «Завдання, основні напрями діяльності та повноваження ДОП» доповнити підпунктом 13 такого змісту: «в межах своїх повноважень всебічно сприяти забез- 
печенню прав і свобод людини, яка $є$ переселенцем із тимчасово окупованих територій»;

- Окремим розділом надати до Інструкції такий підрозділ: «Громадський (позаштатний) працівник поліції», визначивши ним поняття та правовий статус позаштатного працівника поліції.

\section{Література}

1. Гуменюк Л.Й. Поліція і населення: психологічний складник ефективності співпраці. Сучасні стратегї та перспективи оптимізації взаємодії поліції і населення в соціумі : матеріали круглого столу (м. Львів, 23.11.2017). Львів : ЛьвДУВС, 2017. С. 19-22.

2. Про затвердження Інструкції з організації діяльності дільничних офіцерів поліції : Наказ МВС України № 650 від
28 липня 2017 року. URL: https://zakon.rada.gov.ua/laws/ show/z1041-17 (дата звернення: 28.01.2020).

3. Кобзар Г. Громадських помічників дільничних «помножили на нуль». URL: https://vgoru.org/index.php/ politsiya-dlya-gromadi/item/33187-hromadskykhpomichnykiv-dilnychnykh-pomnozhyly-na-nul (дата звернення: 28.01.2020).

4. Про громадські об'єднання : Закон України від 22 березня 2012 року № 4572-VI / Верховна Рада України. URL: https://zakon.rada.gov.ua/laws/show/4572-17 (дата звернення: 28.01.2020).

Медведенко С. В., ад'юнкm

Одеського державного університету внутрішніх справ 